\title{
Practical application of city logistics in the city of Trenčín
}

\author{
Milan Dedík ${ }^{1, *}$, Tomáš Čechovič ${ }^{1}$ and Jozef Gašparík ${ }^{1}$ \\ ${ }^{1}$ Department of Railway Transport, Faculty of Operational and Economics of Transport and Communications, University of \\ Žilina, 01026 Žilina, Slovakia
}

\begin{abstract}
At present, mobility is an important part of everyday activities in cities. The increasing number of passenger and freight vehicles on the widening transport infrastructure raises several problems. The range of use of public passenger transport does satisfy enough the citizens needs and its use is constantly decreasing, especially in the new EU countries. One of the reasons is also the growing sale and production of new passenger cars in the EU, resulting in congestion in the road infrastructure of cities. These issues are dealt with the modern City Logistics concept.The paper is aimed to the basic principles of city logistics, the reasons for its development and, in particular, the possibilities of practical use. An example is the city of Trenčín in Slovakia, where a regional rail passenger transport is proposed for city traffic service including Park and Ride system.
\end{abstract}

\section{Introduction}

High traffic intensity level on the roads currently saturates a great demands on individual transportation. The congestion level is also reflected in the accident rate, which is still very high despite the various measures to reduce them compared to other European countries. Many traffic accidents in cities, as well as high traffic intensity, inadequate capacity of urban communications, result in the emergence of crisis situations. One possible tool for preventing crisis situations in cities is the concept ofCity logistics. This part of logistics is very important, because the movement, transport and handling of material are influential part of the logistical chain.[1]

\section{City Logistics}

The definition of City Logistics follows from the logistics definition: "Logistics is an interdisciplinary science that deals with the coordination, alignment, interconnection and optimization of the materials, information and fiannceflow in terms of customer satisfaction with optimal spending. "City logistics is the process of optimizing logistics and transport activities, involving various companies with the support of advanced information systems in the city with regard to the transport environment and its impact on the emergence of congestion, safety and energy savings. Thereforeone of the tasks of city logistics is to provide comprehensive transport serviceability.[2]

There are cities in Slovakia that are beginning to have problems with the traffic situation, although we can not fully compare the problems of our cities with the problems of major European and world cities. Cities try to handle these situations with different measures and drive as much traffic out of town as possible. Of course, most of these measures, especially construction, have a particular impact on transit traffic, when it is possible to route this kind of out-of-town traffic through the construction of by-pass roads. However, the problem remains with the organization of source and destination traffic that is heading directly to the city. It is precisely the solution to these problems in the cities that gave rise to the emergence of city logistics.[3]

City logistics is part of logistics that deals with issues related to the movement of goods flows and means of transport within the city. Thereforethe primary task is the organization of passenger and freight transport in cities and the organization of goods flows and flows of consignments entering or leaving the city. The main reason for this new direction in logistics was the increase in the number of vehicles in cities.

In the understanding of city logistics, related only to the freight sector, three stakeholders - the carrier, the self-government and the private sector - are involved. It is the triangle of city logistics. If we extend the scope of city logistics to the area of passenger transport, we also need to increase the number of participants who will be involved in the development of solutions. These are, in particular, passenger transport undertakings, police forces and, last but not least, citizens.[4]

The basic principles of city logistics have been elaborated in a number of expert and scientific papers and theses. A comprehensive approach gives Cisarova [5]:"'Given that city logistics is perceived in a number of countries to be essentially negative and not conceptually addressed, it is appropriate to define the preparation and phases that should be preceded by the introduction of a quality global concept. First of all, it is necessary to

\footnotetext{
${ }^{*}$ Corresponding author: tomas.cechovic@,fpedas.uniza.sk
} 
resolve the issue of transit traffic. The city logistics itself solves or should solve only the problems arising from traffic-logistic service, not heavy freight transport. However, there are cities that have major problems with transit, but they are smaller towns with less than 50,000 inhabitants located on busy 1 st and 2 nd class roads. Transit traffic as well as transit traffic can be guided by traffic restrictions".

This issue is also addressed to a large number of transport experts and scientists. For example Julian Allen, Christian Ambrosini, Michale Browne, Daniele Patier, Jean-Louis Routhier and Alan Woodburn [6] propose a wide review of survey methods that have been carried in Europe, based on the conclusions of the BESTUFS II project. From survey work carried out with experts in 11 European countries, a comparison of urban freight transport data collection efforts is made to better understand what currently takes place and to identify examples of good practice. Authors observe that the extent of urban freight data collection varies significantly between the European countries, as existing urban freight data comes mainly from the disaggregation of national survey results. Finally, authors identify a set of gaps in data collection, as well as the need for greater standardization in data collection methods and in analysis and reporting of this data.

Jesus Gonzalez-Feliu, Routhier, J. L et al [6] propose a statistical-based modeling approach to propose a data estimation tool that can be transposed to different cities, avoiding the needs of making very costly surveys. The proposed framework needs standard inputs able to be obtained by public authorities and/or private stakeholders to make a diagnosis of urban logistics in current situations. The joint process of collecting data and modeling is described, and the different modules of the framework are presented. The authors conclude by presenting the main applications and further developments.

However, at present, it is important to address, in particular, the solution of city logistics in passenger transport. Therefore, it is necessary to be able to correctly define the reasons for the development ofthe city logistics and especially the opportunities of its use in practice.

\subsection{Reasons for creating the city logistics}

There are a number of reasons why city logistics is becoming more and more important. These include[7]:

- Environmental: the negative impacts of transport on its surroundings are generally known (noise, exhales, soil cover, etc.). By proposing effective solutions to urban and freight transport in cities, these negative impacts can be reduced;

- Transport: the road network in the cities has been diminished during its construction to a lower capacity. Today, however, the traffic flow is far higher than previously thought. Therefore, measures in city logistics can at least partially solve this situation;
- Living standards in the city: the city is a place for its inhabitants to provide not only their living needs but also their social needs. Improving the living standards of city residents can greatly help to improve the traffic situation, mitigate negative environmental impacts, or reduce traffic in the chosen area or time.

\subsection{Opportunities for solving urban problems in practice}

Solving problems related to increasing the number of vehicles in cities can be solved in a number of ways, but finding an optimal solution is not easy. City Logistics offers a lot of suitable logistics concepts for passenger and freight transport optimization, which usually consist of one or more combinations of the following city logistics approaches[8]:

- Vehicle entry restrictions or permissions; depending on the type of vehicle (size, weight, amount of produced emissions), vehicle entry is permitted or prohibited in a particular area. Mostly, the weight limit applies to the total weight and width of the vehicle or to certain emission limits.

- Paid communications and toll-road fee system; in this case, to introduce tolls for selected types of vehicles that are interested in entering the marked part of the city that is subject to the city toll system [9]. This solution can reduce the number of unacceptable vehicles on toll roadson the one hand, and it can be beneficial for the city budgeton the other hand,

- Night supply; when the supply is done at night, the vehicles are avoided by the daily traffic peaks while not feeding them. This results in benefits such as shorter driving times, the possibility of using larger vehicles to replace several small ones, reducing emissions and fuel consumption, fewer roads,

- Distribution of goods by other means of transport. By introducing this measure, a modal shift of the goods to ecologically acceptable modes of transport should be achieved, and consequently the less number of journeys,

- Making urban transport more attractive; only the high-quality, fast-moving urban public transport at regular intervals should motivate citizens to prefer public passenger transport to individual motoring.

- The use of the urban rail transport kindsas a main means of transport; in large cities with built-up tramways, overground and underground railways (metro), this mode of transport should form a transport system and should provide passengers an attractive concept of transport.

- Utilization of the rail network (or private sidings) for city traffic service. Several railway lines in many cities pass relatively close to the center and there is a low number of trains. There are also unused private sidings. [9] In this case, there is a possibility of the new trains intoduction as public transport, whereby these trains will use the existing regional or main lines orprivate sidings. 
- Support for the walking and cycling by building of the paths and cycle tracks.

\section{Practical use in the city of Trenčín}

The city of Trencin lies in the western part of Slovakia in the Trenčianska highlands, which extends along the valley of the river Váh. I tis divided into four major city districts - the middle, south, north and west, which are further decomposed into smaller units. According to the population survey in January 2018, Trenčín had a total of 54,916 inhabitants. It is possible to rank it on the 8th place among 140 Slovak towns.
There is a problem with an excessive increase individual car transportation in the city of Trencín and thus also congestion. Instead of creating alternatives for the city to create a parking space on the fringe of the city before entering its center, the large number of cars park directly in its narrow center and core, resulting in an increase in the number of cars in the city center. Although the city charged almost all the parking places in the center and close the city center, the problem has not been solved yet.If there is no option to park the motor vehicle in the parking garages on the periphery, the drivers will have to park their vehicle in the city center.[10]

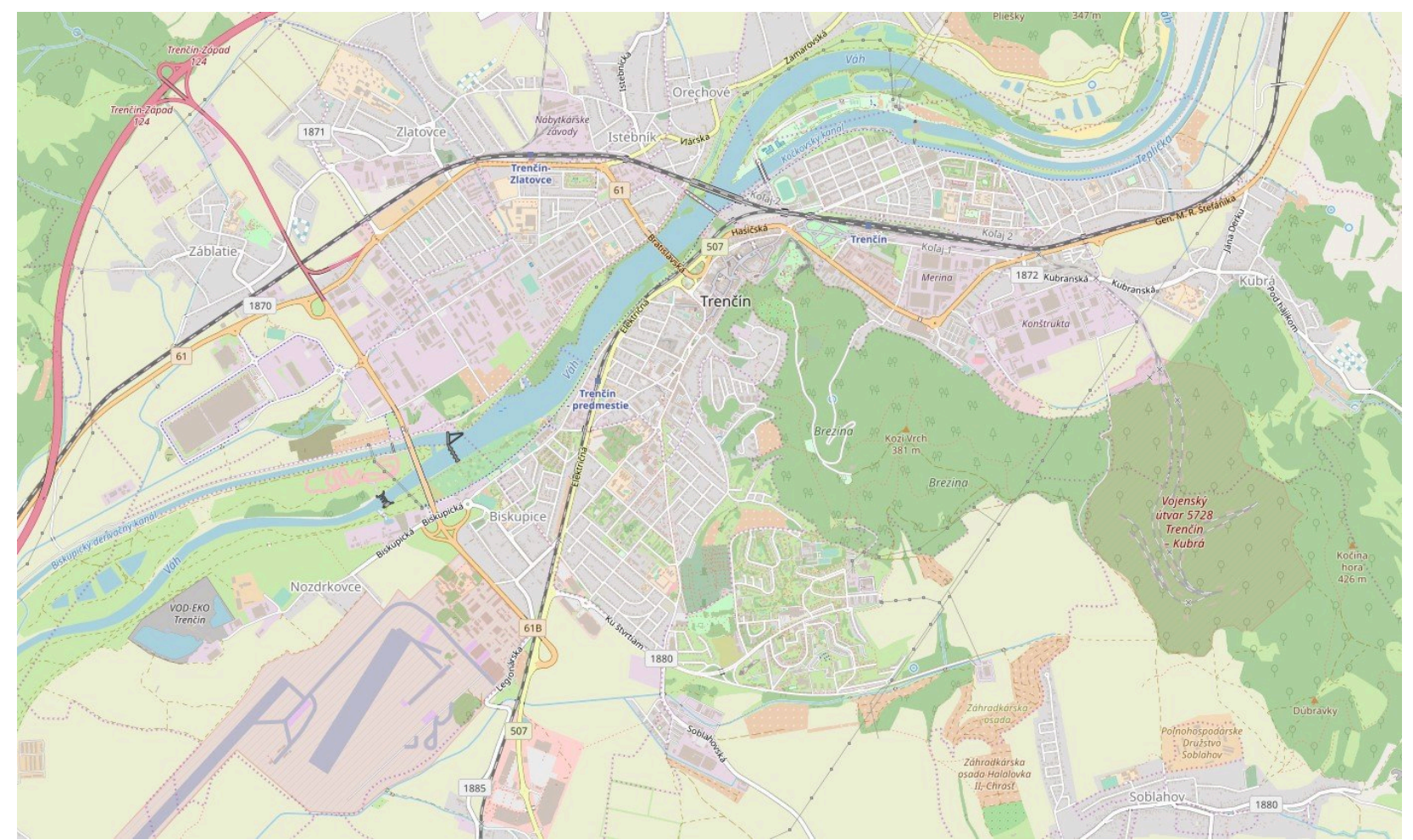

Fig. 1. The map of railway and road infrastruktur of Trenčín: [15]

\subsection{The proposal of solution by using rail transport}

In accordance to the city logictic concept is proposed to extensive usage of rail transport. A suitable way to solve the present situation is to use the existing railway lines or private sidings passing through the city of Trenčín and ensure their operation at dense intervals, thus creating the "Urban railway transport". This should create an alternative way to go through the city by a private car in order to connect the city center with its other parts more efficiently.

Start of the route is proposed on the rail leading to the area of military siding on the estate housing „Pred Pol'om" and continues through the railway station Trenčín, further down the railway line no.143 through the stop „Trenčín - predmestie“ to, Trenčianska Turná“ as the final stop where the train units will change direction. The private siding belongs to the Slovak
Army, there is an average of 1 train per year, and its use is very problematic but possible.

The proposed route should cooperate together with the proposed parking and applying appropriate measures, such as the cost of using these car parks, which should include the ticket to proposed train. In addition to the priority objective, an alternative to public transport buses will also be created along the entire route. Thus, not only the city's inhabitants, but also the entrants can go from one side of Trenčín to another or to the city center and back more faster.

The calculation of the interval run from the new „Pred Pol'om“ stop to „Trenčianska Turná“ station at the intended average speed of $35 \mathrm{~km}$ per hour and the total distance 6,720 meters, which is considered with 30 seconds additional time for the motor starting run and stopping, and 30 seconds for the dwell timein 10 of 12 stops during the whole ride, the result of running timeis 20.5 minutes. It means the train units should ensure the entire territory traffic servicetheoretically over 20 minutes. Also they would do three backruns during one 
hour if they did not give priority to any other passengersor freight train.[9]

There are proposed total 12 stops in the given order, with 3 already existing:

Pred pol'om(A) - starting or the final stop, which could be built at the estate housing, on the private siding leading to a military area. It should ensure transport services to this city part and a small part of Kubra.

Merina (B) - a stop just before the railway station Trenčín. Its name is derived from the nearby Merina building, but it can ensure transport service in the Sihot' city part. It has an important strategic location because of the big parking place.

Railway station (C) - one of the already existing stops for this route, its strategic location would make it possible to ensure transport service in the most of Sihot' I. part and part of Milan Rastislav Štefánik Park to supermarkets Billa and Lidl as well as the available MERINA area.

Hasičská (D) and Zátoka pokoja (Bay of Peace) (E) - these two stops are the closest and the most accessible to the historical center of Trencin. The entire center and the beginning of Kolar's quarter are available from these stops. There is a subway crossingat the Hasičská streetthat would serve the passengers for easy access to the stop. Similarly, it is also at the stop of the Bay of Peace, where there is already an existing level crossing.

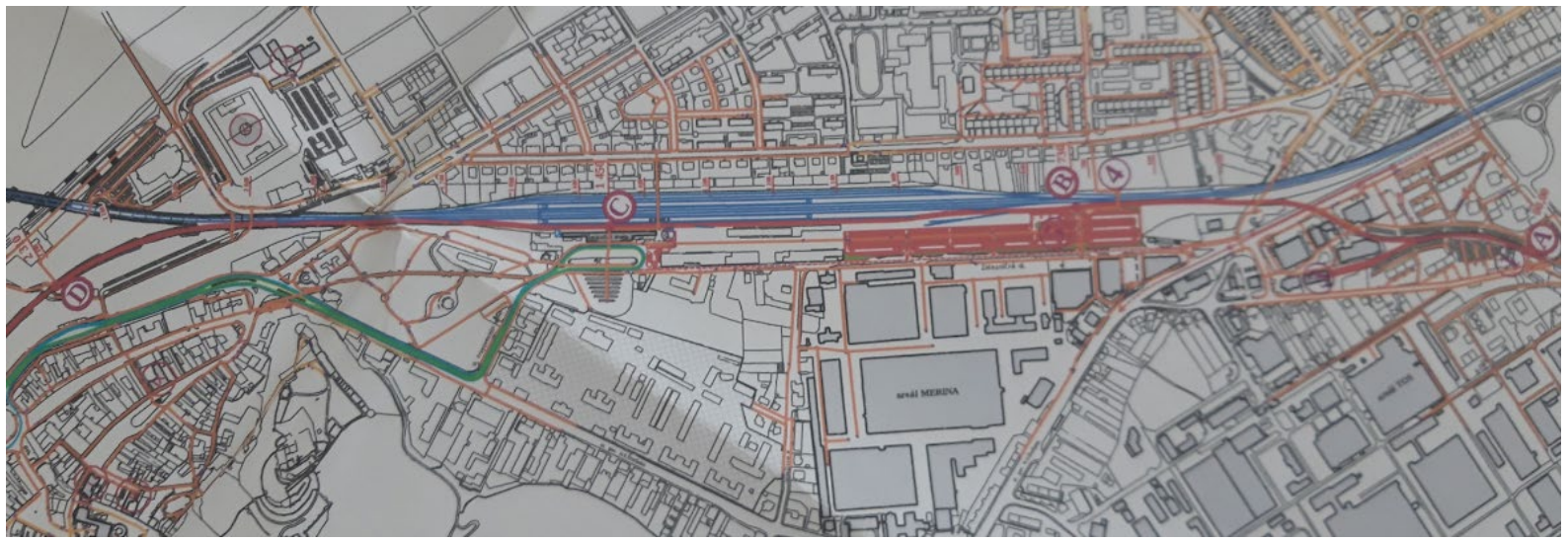

Fig. 2. Stops A - E and car park next to B stop, Source: [9]

Predmestie (Suburb) (F) - one of the existing stops currently used by passenger trains near the clinic and the District Court. There is a subway crossing at the stop. In addition there is proposed to build an overtaking station. There will be ensured safe and crossing of the both trains.
Hospital (G)-the location of this stop is near to the hospital and the city part „Noviny“, where is the subway crossing.

Noviny (H) and Kaufland (I) - these proposed stops sholud ensure transport service od the area from the hospital to Kaufland, as well as residential areas in the Legionary Street and Biskupice district.

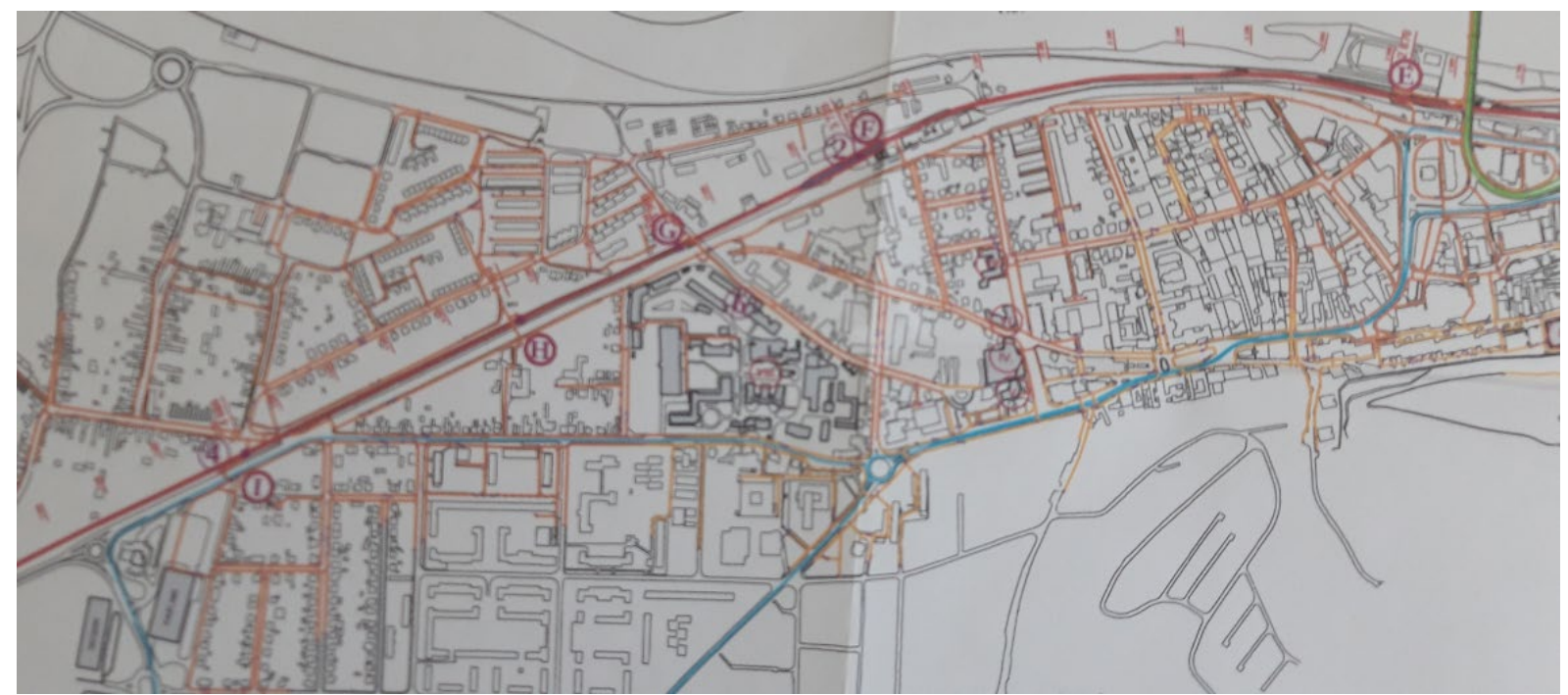

Fig. 3. Stops E - I, Source: [9]

Dial'ničný privádzač (Highway feed) $(\mathbf{J})$ - there is no residential area or large residential buildings. Therefore, it is primarily intended for the arrival and exit of passengers who will come from motorway and will parked their vehicles in a parking place and consequently go the city center. There must be build an upperbridge 
over the route no. 507 because of safe and easy passenger access to the stop.

Tesco (K) - the stop is close to the Tesco and Laugaricio shopping centers.

Trenčianska Turná (I) - the final stop of this planned route in the figure depicted by the letter "L",
The train units will change their travel direction at this railway station. It will also ensure transport services of the entire Trenčianska Turná and to transport passengers to and from the city center, who have parked their vehicles at the proposed parking places next to the railway station Trenčianska Turná.[9]

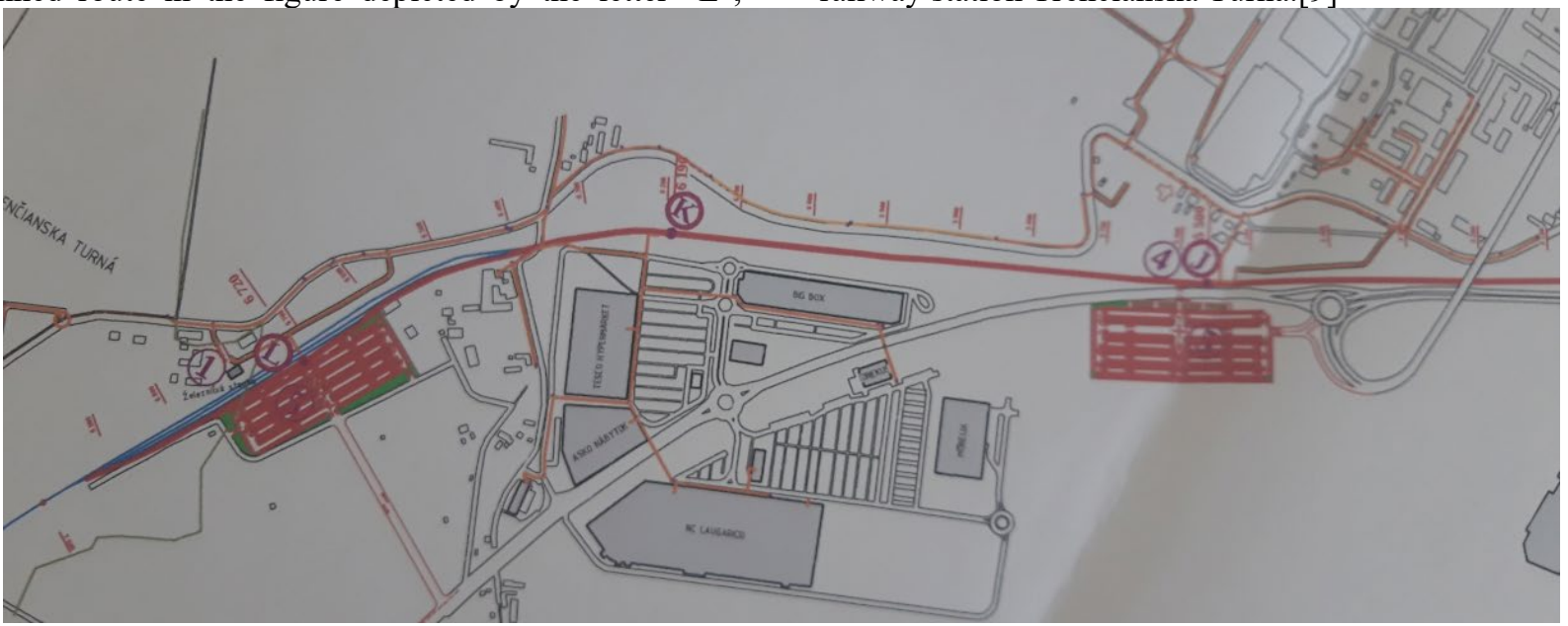

Fig. 4. Stops J -L and 2 car parks next to L and J stops, Source: [9]

\subsection{Usage of the Park and Ride transport system}

One of the most widespread problem-solving systems in the city is Park and Ride (P \& R), "park and go by public transport". The P \& R system is a typical application of intelligent transport systems. It includes parking places and other facilities that enable the interconnection of individual and public transport and combine their advantages. The basic task is to enable an advantageous transfer to urban public transport, thus reducing the number of passengers to the city center by individual transport.

On the proposed transport route is important to build three catch car parkings in front of the center of Trenčín. The first car parking (A) would serve for cars coming from Banovce nad Bebravou. The parking is designed in the area between the railway and the existing local road, located at the railway station at the beginning of Trenčianska Turná. The second car parking (B) should be built at a downhill run from the D1 highway, which should primarily serve to shut-down cars from the D1 motorway and to offer them the possibility of parking in the contact with rail transport.

Another proposed car parking (C) should be next to the Trenčin railway station, in the unused warehouse building area. This strategic location of the car parking should enableto be parked the vehicles coming from Trenčianska Tepláand to offer the possibility of parking in the contact with rail transport too. $[11,12]$

\subsection{The proposal of the possible timetable}

When timetable construction,passenger trains for transport services and thus serving as a train service for public transport, it is very important to offer as many connections as possible in dense time intervals. This philosophy is also respected in the construction of passenger trains for transport services in the city of Trenčín. However, in order to maintain the line and station intervals on the line section after the overtaking stationconstruction at the stop, it is possible to ensure a 22-minute full-day interval of the proposed passenger

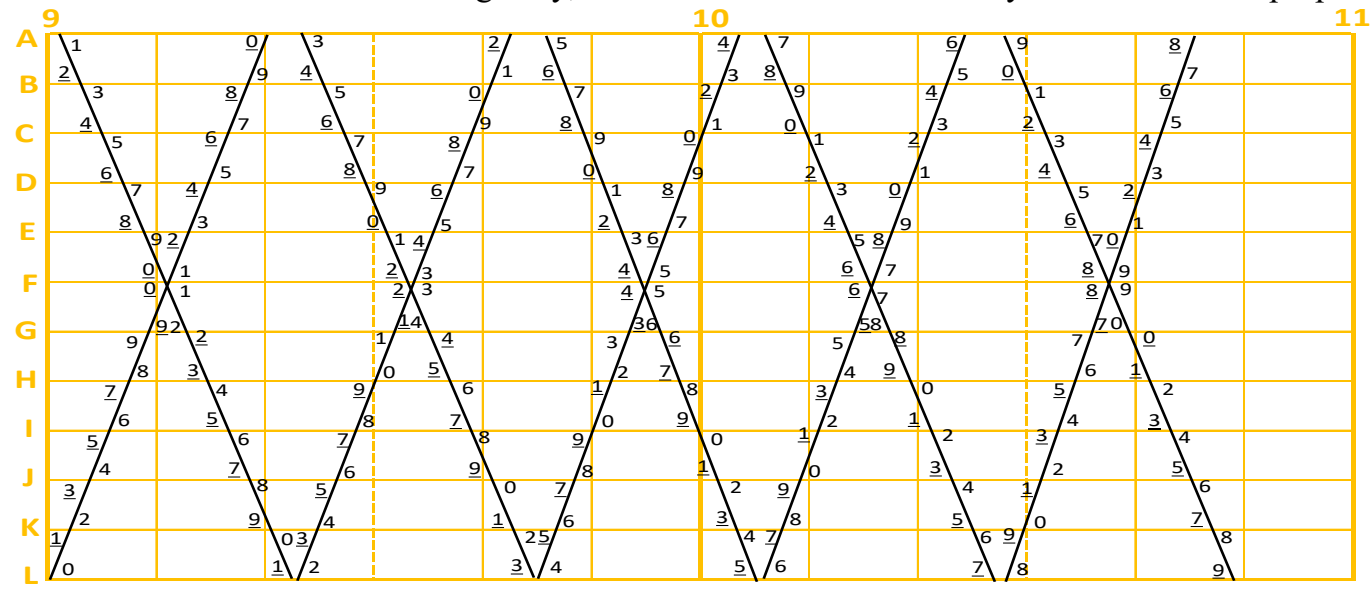

Fig. 5. A preview of two hours period train traffic diagram, Source: [10] 
trains. Crossing of the passenger trains is ensured at the overtaking stationTrenčín - Predmestieand at Trenčianska Turná station. Running times on the route are recalculated for the 813/913class of the train unit. A preview of a possible train traffic diagramfor two hours periodis shown on the Figure 4.[13, 14]

\subsection{Benefits and risks of the proposal}

In the final assessment of the proposal, it was found that the implementation of the proposal should result in a significant reduction in individual car traffic in the city, thereby reducing congestion. Also the cancellation of some car parks in the city center should be replaced by greenery, which would reduce the number of vehicles in the city, reduce greenhouse gas emissions, and thus improve environmental impacts. After building a overtaking station, train units should drive for a minute accurately and on time. It is a very important criterion in terms of time aspect of choosing the right means of transport to the city center.

The only possible risk and collision point within the entire planned section is the level crossing of the line leading to the private siding object, to the „Pred Pol'om"stop and Gen. M. R. Štefánik street. It's the only place to meet a passenger car with the railway vehicle. A solution for this risk would be to ensure this collision point by light signaling and barriers. The next collision point is also possible to consider the overtaking station where passenger and freight trains will be crossed, but the correct timing of the timetable with regard to the current range of train traffic can help to avoid the problems.[15]

\section{Conclusion}

At present, mobility is a part of everyday activities in cities. The increasing number of passenger and freight vehicles on the widening transport infrastructure causes a number of problems that can not be solved alone, but also in terms of impacts on the whole area. The simiral problems are in the city of Trenčín. The measures, that have been taken so far, have not been able to disburden the city from frequent congestion and traffic collapse. These problems preclude to improve the transport service in the city.

Due to this persistent unfavorable situation in the city of Trenčín, the purpose of the contribution was to propose measures for the use of regional passenger railway transport for the city transport service. To meet this goal, specific measures have been proposed for the deployment of the transport system and technology together with a regional rail transport. For Trenčín, the proposal brings new alternatives to solve the transport problems and to reduce the intensity of individual car traffic, thus relieving the city center from a large amount of road traffic. At the same time it supports public transport systems and also the use of regional rail transport, thereby improving the ecological and environmental aspects of the city.[12]
The proposed concept that is being considered in Trenčín, should become a key global technology in urban logistics. It should help optimize passenger transport in cities and tackle global transport problems.

The paper is supported by the VEGA Agencyunder Project 1/0095/16, 'Assessment of the quality of connections on the transport network as a tool to enhance the competitiveness of public passenger transport system', that is solved at Faculty of Operations and Economics of Transport and Communication, Universityof Žilina.

\section{References}

1. D. Vidriková. Crisis Management, 9. 2, (2010), online available: http://fsi.uniza.sk/kkm/files/admincasopis/KM\%202 \%202010/ODBORNE/Vidrikova.pdf

2. M. Kendra, J. Mašek. Perner's Contacts, 3, no. 3 (2008)

3. L. Pečený, J. Gašparík, V. Gáborová, ICTTE Belegrad 2016: Proceedings of the 3rd International Conference on Traffic and Transport Engineering 462-466, (2016)

4. T. Skrúcaný M. Kendra, M. Škorupa M. Conference: 12th International Scientific Conference of Young Scientists on Sustainable, Modern and Safe Transport, 806-81, (2017)

5. H. Cisarova "Modelling of transport services in the selected area using city logistics." in Czech, Dissertation thesis, University of Pardubice, (2012)

6. C. Ambrosini, \& J. L. Routhier, Transport Reviews, 24(1), 57-77. (2004)

7. M. Dedík, J. Gašparík, Z. Záhumenská, Logi 2017, Conference Proceedings, 18th International Scientific Conference, 134, (2017), DOI: 10.1051/matecconf/201713400009.

8. .J. Blašković, B. Abramović, D. Šipuš,. International Journal for Traffic and Transport Engineering (IJTTE) 7(4), 430-442 (2017)

9. T. Čechovič "Advisement of the use of a regional railway transport on the city Trenčin" in Slovak, Diploma thesis, Žilinská univerzita v Žiline, Slovakia, 2018

10. M. Kvizda, Rewiew Of Economic Perspectives. 17, 3 331-334. (2017)

11. TRENCIN-INAK.SK, 2018. Online available: http://www.trencin-inak.sk/actuality.php

12. L. Bartuska, V. Biba, R. Kampf. Proceedings of the Third International Conference on Traffic and Transport Engineering. (ICTTE), 900-904 (2016)

13. Š. Kudláč, J. Majerčák, P. Majerčák, Transportation Research Procedia, 28, 45-50..( 2017)

14. TRENCIN.SK, 2018. Online available: https://trencin.sk/pre-obcanov/o-meste/mapy-mesta/ 